CLINICAL STUDY

\title{
Relationship between adiponectin levels, acylated ghrelin levels, and short-term body mass index changes in children with diabetes mellitus type 1 at diagnosis and after insulin therapy
}

\author{
Gabriel Á Martos-Moreno, Vicente Barrios, Leandro Soriano-Guillén and Jesús Argente \\ Department of Endocrinology, Hospital Infantil Universitario Niño Jesús, Universidad Autónoma de Madrid, E-28009 Madrid, Spain \\ (Correspondence should be addressed to J Argente; Email: argentefen@terra.es)
}

\begin{abstract}
Objective: To determine the effect of the initial metabolic imbalance and its restoration after insulin therapy on adiponectin and acylated ghrelin levels in children with type 1 diabetes mellitus (T1DM). Study design: Twenty prepubertal children with newly diagnosed T1DM were prospectively studied at diagnosis and after 1 and 4 months of therapy. Body mass index (BMI) and serum levels of adiponectin, resistin, total and acylated ghrelin, leptin, tumor necrosis factor $\alpha$ (TNF- $\alpha$ ), and interleukin-6 (IL-6) were determined. The control group comprised 40 healthy prepubertal children.

Results: BMI was decreased at diagnosis, normalized at 1 month, and remained so thereafter. Adiponectin levels at diagnosis were similar to controls, increasing significantly after 1 month and normalizing at 4 months. Acylated ghrelin levels were lower at diagnosis, with a significant increase at 1 month and normalizing at 4 months. Resistin levels were normal at all time points. Leptin levels were decreased, while TNF- $\alpha$ and IL- 6 were increased at diagnosis and normalized at 1 month.

Conclusions: These findings suggest that BMI is not the main predictor of acylated ghrelin or adiponectin levels in newly diagnosed T1DM subjects and that these peptides may play an important role in the metabolic adaptation in this disease.
\end{abstract}

European Journal of Endocrinology 155 757-761

\section{Introduction}

The improper regulation of glucose and lipid metabolism due to the lack of insulin in type 1 diabetes mellitus (T1DM) leads to an increased lipolysis rate and decreased stored fat tissue, which is reversible after insulin administration (1). Adipose tissue has been discovered to be an endocrine organ; hence, changes in fat mass could have a relevant influence on its hormonal and metabolic role (2).

Adiponectin, a hormone produced specifically in adipocytes, acts mainly on skeletal muscle and liver, increasing insulin sensitization, and inhibiting key gluconeogenic enzymes $(3,4)$. Its levels are negatively correlated with body mass index (BMI) and fat content (5), and tend to normalize when weight control is achieved (6). Resistin has also been associated with obesity and insulin resistance in murine models, although its role in humans remains unclear (3). Hyperglycemia and hyperketonemia induce proinflammatory cytokine production (7), which is modified after insulin treatment (8). Adipose tissue produces interleukin-6 (IL-6) and tumor necrosis factor $\alpha$ (TNF- $\alpha$ ), which are related to BMI and fat stores, modulating adiponectin gene expression and increasing insulin resistance (9).

Circulating levels of leptin and ghrelin correlate with body fat content throughout normal childhood development, as well as in obesity and anorexia $(10,11)$. Both peptides play a role in glucose metabolism and we previously reported reduced total ghrelin levels in T1DM children, as well as after oral glucose overload in obese children $(12,13)$. Later, T1DM patients were reported to have low acylated ghrelin levels (14), after the discovery of this form as the specific ligand of the growth hormone secretagog type 1a (GHS1a) receptor, and as having important physiological roles such as stimulation of glucose output from hepatocytes, whereas non-acylated ghrelin has the opposite effect (15).

Due to their relationship with fat stores and insulin sensitivity, these peptides could be involved in carbohydrate and lipid metabolism in children with T1DM. Therefore, the aims of this study were to analyze the circulating levels of adiponectin, resistin, total and acylated ghrelin, leptin, TNF- $\alpha$, and IL-6 in T1DM children at diagnosis and after 1 and 4 months of insulin therapy and determine the relationship between these variables, as well as with metabolic and anthropometric data. 


\section{Subjects and methods}

\section{Subjects}

Twenty prepubertal (Tanner stage I) children (ten boys and ten girls) with newly diagnosed T1DM, mean age $7.34 \pm 0.88$ years, admitted to the Hospital Infantil Universitario Niño Jesús from January to July 2004, were studied for 4 months. All patients had abrupt diabetes onset with classical symptoms, although they were not severely impaired $(\mathrm{pH} 7.31 \pm 0.02)$. None of the patients entered puberty during the study.

Patients were treated with i.v. fluids and either continuous i.v. insulin infusion $(n=10$, doses between 0.05 and $0.1 \mathrm{IU} / \mathrm{kg}$ per $\mathrm{h}$ ) or short acting s.c. insulin every $4 \mathrm{~h}(n=10$, doses between 0.6 and $1 \mathrm{IU} / \mathrm{kg}$ per day). After 48-60 h, they were started on a split-mix regimen of s.c. NPH and short-acting insulin analog (Lis-pro).

Forty healthy Tanner stage-, age- and sex-matched children (20 girls and 20 boys) composed the control group. Their mean age was $8.16 \pm 0.46$ years, BMI SDS $-0.1 \pm 0.35$, height SDS $0.0 \pm 0.13$, and weight SDS $-0.16 \pm 0.13$ according to Spanish standards (16).

Blood samples were collected at diagnosis before insulin therapy (Dx), and after $1(1 \mathrm{M})$ and 4 months $(4 \mathrm{M})$. All samples were obtained after overnight fasting, except at the onset of the disease. None of the patients enrolled had eaten for $3 \mathrm{~h}$ prior to diagnosis. All patients and their parents gave informed consent as required by the local ethics committee, which had previously approved the study.

\section{Biochemical measurements}

Adiponectin, and total and acylated ghrelin levels were measured by RIA (LINCO Research, Inc., St Charles, MO, USA). Intra- and interassay coefficients of variation (CV) were 3.9 and $8.5 \%$ for adiponectin, 6.4 and $16.3 \%$ for total ghrelin, and 7.4 and $13.4 \%$ for acylated ghrelin respectively. Resistin was determined by ELISA (LINCO Research, Inc.). Intra- and interassay CV were 4.5 and $7.4 \%$ respectively. Ultrasensitive ELISAs were used for TNF- $\alpha$ and IL- 6 determination (Quantikine HS; R\&D Systems, Inc., Minneapolis, MN, USA). Intra- and interassay CV were 6.7 and $13.3 \%$ for TNF- $\alpha$ and 7.4 and $7.8 \%$ for IL- 6 respectively.

C-peptide was determined by RIA (Diagnostic Systems Laboratories-7000) and islet cell antibodies (ICA) by indirect immunofluorescence at $1 \mathrm{M}$ (17). Glucose, insulin, leptin, and $\mathrm{HbA} 1 \mathrm{c}$ were measured as previously reported (12).

\section{Statistical analysis}

Data are reported as the mean \pm s.D. Analysis was performed by one way ANOVA with Bonferroni and Dunnett's tests for post hoc comparisons, followed by Student's $t$-test or Wilcoxon 2-sample test. The relationships between variables were determined by linear regression analysis after log transformation. A value of $P<0.05$ was chosen as the level of significance. Statistical analyses were performed using SPSS 12.0 software for Windows (MapInfo Corporation, Troy, NY, USA).

\section{Results}

As no differences were found between sexes in any variable, values were analyzed together. Every diabetic patient had detectable circulating ICA, ranging from 20 to 320 juvenile diabetes foundation units, as well as C-peptide levels below the detection limit of the assay $(0.5 \mathrm{ng} / \mathrm{ml})$.

Serum glucose levels were higher at diagnosis $(365 \pm 124 \mathrm{mg} / \mathrm{dl} ; P<0.001)$ than at later time points $(1 \mathrm{M}, 133 \pm 47 \mathrm{mg} / \mathrm{dl} ; 4 \mathrm{M}, 151 \pm 64 \mathrm{mg} / \mathrm{dl})$. The insulin dose was higher at diagnosis $(0.72 \pm 0.21 \mathrm{IU} / \mathrm{kg}$ per day; $P<0.001)$ than at $1 \mathrm{M}$ or $4 \mathrm{M}(0.35 \pm 0.21$ and $0.48 \pm 0.13 \mathrm{IU} / \mathrm{kg}$ per day respectively). No differences were found in $\mathrm{HbAlc}$. The BMI increased at $1 \mathrm{M}$ (Dx $-0.85 \pm 0.45$ vs $1 \mathrm{M}-0.16 \pm 0.37, P<0.05)$ remaining unchanged at $4 \mathrm{M}(-0.14 \pm 0.56$; Fig. $1 \mathrm{~A})$.

At diagnosis, adiponectin levels were similar to controls $(9.94 \pm 3.69($ median $=9.82$, range $=8.10)$ and $10.30 \pm$ $3.22 \mu \mathrm{g} / \mathrm{ml}($ median $=9.57$, range $=11.40)$ respectively $)$. However, at $1 \mathrm{M}$ adiponectin increased $(12.43 \pm$ $5.59 \mu \mathrm{g} / \mathrm{ml}($ median $=11.40$, range $=9.38) ; P<0.05)$, normalizing at $4 \mathrm{M}(9.89 \pm 4.08 \mu \mathrm{g} / \mathrm{ml}$ (median $=10.27$, range $=8.84$ ); Fig. 1B).

Total ghrelin remained decreased and unchanged throughout the study (Dx 912 \pm 451 (median $=852$, range $=1311), 1 \mathrm{M} 888 \pm 253($ median $=890$, range $=$ $675)$ and $4 \mathrm{M} 905 \pm 503($ median $=871$, range $=1128)$ versus controls $1350 \pm 638 \mathrm{pg} / \mathrm{ml}$ (median $=1270$, range $=1246$ ); $P<0.05$; Fig. $1 \mathrm{C}$ ).

Acylated ghrelin was decreased at diagnosis compared with controls $(50.2 \pm 20.2$ (median $=47.4$, range $=52.5)$ vs $80.0 \pm 37.2 \mathrm{pg} / \mathrm{ml}$ (median $=79.6$, range $=60.3$ ); $P<0.05)$, rose at $1 \mathrm{M}(1 \mathrm{M} 92.4 \pm 86.8 \mathrm{pg} / \mathrm{ml}$ (median = 79.2, range $=120.9) ; P<0.05$ versus $D x$ and $P<0.05$ versus controls) and normalized at $4 \mathrm{M}(64.4 \pm$ $37.0 \mathrm{pg} / \mathrm{ml}$ (median = 73.2, range $=113.1$ ); Fig. 1D).

Leptin levels were decreased at diagnosis compared with controls $(2.7 \pm 1.7($ median $=2.5$, range $=4.3)$ vs $5.1 \pm$ $3.7 \mathrm{ng} / \mathrm{ml}$ (median $=4.6$, range $=6.3), P<0.001)$, normalizing afterwards $(1 \mathrm{M} 5.2 \pm 3.8 \mathrm{ng} / \mathrm{ml}($ median $=4.8$, range $=5.0) ; 4 \mathrm{M} 6.1 \pm 3.4($ median $=5.6$, range $=5.4)$; Fig 1E).

No differences in serum resistin levels were found between controls $(8.0 \pm 3.8 \mathrm{ng} / \mathrm{ml}$ (median $=7.9$, range $=12.1)$ ) and patients at any time point $(\mathrm{Dx}$ $7.2 \pm 3.8($ median $=7.5$, range $=10.6), 1 \mathrm{M} 7.7 \pm 4.3$ $($ median $=7.9$, range $=9.4)$, and $4 \mathrm{M} 6.5 \pm 3.4 \mathrm{ng} / \mathrm{ml}$ $($ median $=5.4$, range $=8.8)$; Fig. $1 \mathrm{~F})$. 

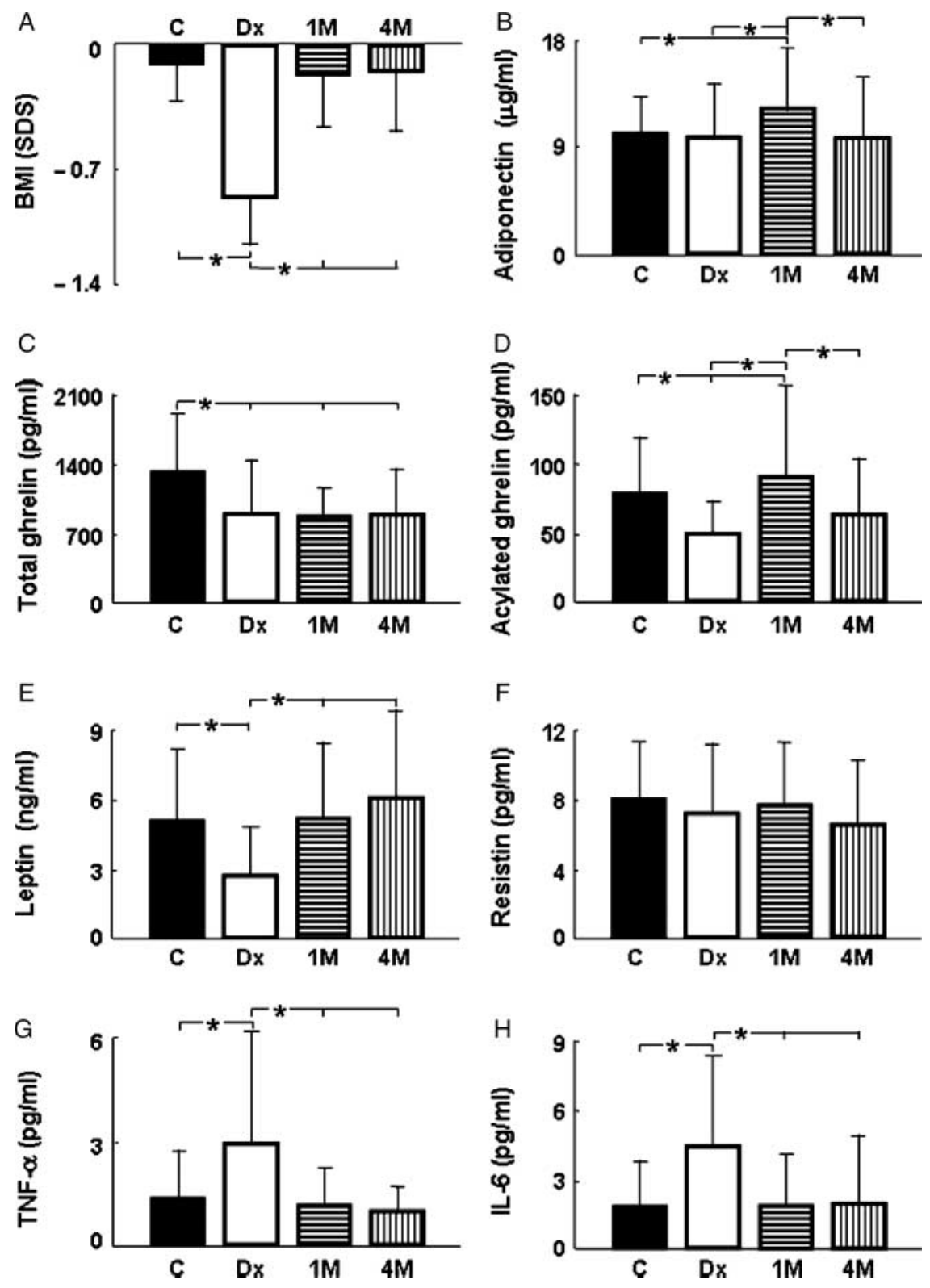

Figure 1 Mean \pm S.D. values of $(A)$ body mass index (BMI), (B) serum adiponectin, (C) total ghrelin, (D) acylated ghrelin, $(\mathrm{E})$ leptin, $(\mathrm{F})$ resistin, $(\mathrm{G})$ tumor necrosis factor- $\alpha$ (TNF- $\alpha$ ), and $(\mathrm{H})$ interleukin-6 (IL-6) levels in children with type 1 diabetes mellitus $(n=20)$ and age- and sex-matched controls $(n=40)$. $\mathrm{C}$, control group; Dx, patients at diagnosis; $1 \mathrm{M}$, patients after 1 month of insulin therapy; $4 \mathrm{M}$, patients after 4 months of insulin therapy. ${ }^{*} P<0.05$.

Circulating TNF- $\alpha$ was increased at diagnosis compared with controls $(3.0 \pm 3.1$ (median $=3.6$, range $=6.6)$ vs $1.4 \pm 1.2 \mathrm{pg} / \mathrm{ml}($ median $=1.3$, range $=2.3), P<0.05)$, normalizing at $1 \mathrm{M}(1.2 \pm 0.9 \mathrm{pg} / \mathrm{ml}$ (median $=1.3$, range $=2.1)$, and remaining stable at $4 \mathrm{M}(1.1 \pm 0.9$ (median $=1.1$, range $=0.9)$; Fig. 1G). IL-6 levels exhibited the same pattern, high at diagnosis $(4.6 \pm 4.7 \mathrm{pg} / \mathrm{ml}$ $($ median $=3.3$, range $=8.0)$ vs controls $1.8 \pm 1.8 \mathrm{pg} / \mathrm{ml}$ $($ median $=1.5$, range $=4.2) ; P<0.01)$, normal at $1 \mathrm{M}$ $(1.9 \pm 2.1 \mathrm{pg} / \mathrm{ml}($ median $=1.3$, range $=4.7))$ and $4 \mathrm{M}$ $(2.0 \pm 3.4($ median $=1.3$, range = 5.3); Fig. $1 \mathrm{H})$.

A correlation was found between the logarithms of adiponectin and acylated ghrelin levels in patients at diagnosis $(r=0.76, P<0.01$; Fig. $2 \mathrm{~A})$, but not after insulin therapy or in controls (Fig. 2B). A positive correlation between BMI and leptin levels was found only in controls $(r=0.59, P<0.01)$. No other significant correlations were found.

\section{Discussion}

Here, we demonstrate that at diagnosis, diabetic patients have decreased BMI serum leptin, and total and acylated ghrelin levels, while IL- 6 and TNF- $\alpha$ are increased with no change in resistin or adiponectin. After 1 month, BMI, leptin, TNF- $\alpha$, and IL-6 normalize, while adiponectin and acylated ghrelin increase above 


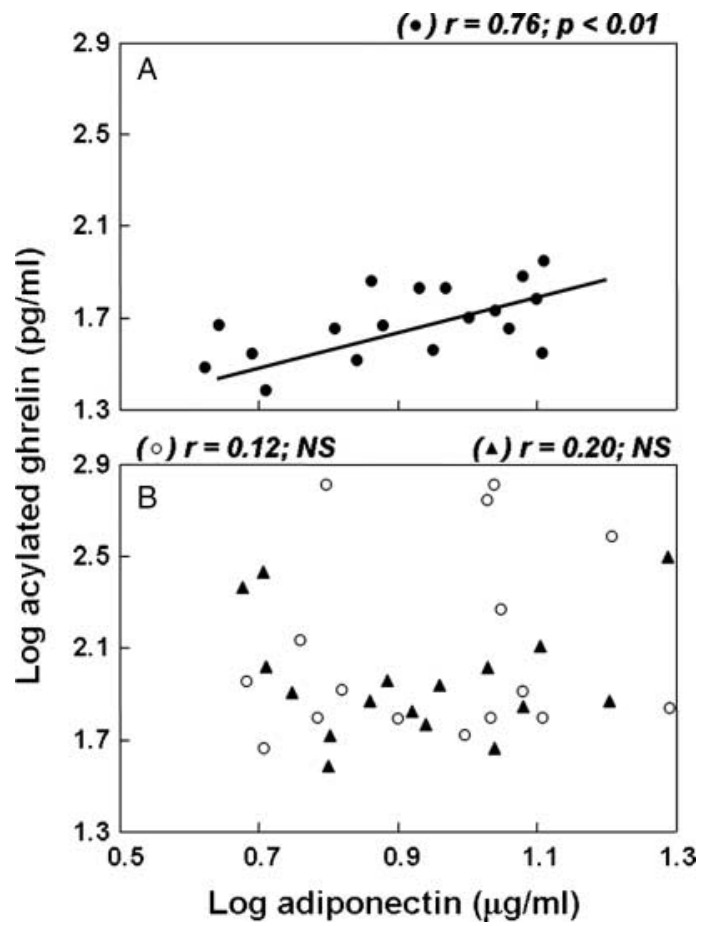

Figure 2 Linear regression analyses between logarithms of adiponectin and acylated ghrelin levels in type 1 diabetic children $(\mathrm{A})$ at diagnosis and $(\mathrm{B})$ after $1(\mathrm{O})$ and $4(\mathbf{A})$ months of insulin therapy.

control values. Total ghrelin remains decreased and resistin is unchanged. After 4 months, only total ghrelin remained decreased.

Acylated ghrelin is reported to stimulate hepatic glucose output (15) and to decrease insulin levels (18) and sensitivity (19). Therefore, the low acylated ghrelin levels found in our patients at diagnosis could be a protective mechanism against hyperglycemia. Their increase after 1 month could be a result of exogenous insulinization due to acylated ghrelin's ability to favor glucose disposal and to modulate insulin sensitivity. After 4 months, when metabolic stabilization is reached, its levels would not be expected to differ from normal subjects, as observed in our patients, although long-term reduced levels have been postulated as a compensatory mechanism to restrain fat-mass gain after initial refeeding (14). The 3-h fasting prior to diagnosis could be considered insufficient for comparisons with later fasting samples; nevertheless, the chronic hyperglycemia and lipolysis state of these patients should be major metabolic determinants, much more than time of fasting.

Low initial BMI was probably not due to dehydration, as no significant increase in BMI after intensive i.v. rehydration was found, possibly due to the lack of severity in our patients at diagnosis. The parallel recovery of BMI and leptin after 1 month suggests an increase in adipose tissue $(1,20)$. The decreased BMI and need for increased insulin sensitivity would make one expect increased adiponectin at diagnosis $(5,21)$; however, the high TNF- $\alpha$ and IL-6 could impair adiponectin gene expression and plasma levels $(9,22)$. Also, abrupt reduction of caloric intake and weight loss decreases adiponectin levels (23), suggesting that they are not only related to BMI.

The positive correlation between acylated ghrelin and adiponectin at diagnosis that disappears after insulin therapy suggests an adaptive mechanism to metabolic impairment influenced by hyperglycemia, fasting, and proinflammatory cytokines. Normalization of TNF- $\alpha$ and IL- 6 and restoration of carbohydrate usage may be responsible for the increment in adiponectin despite initial BMI recovery. Moreover, as insulin downregulates adiponectin receptor expression, insulin replacement could induce adiponectin resistance (24), making increased levels necessary to achieve the physiological effects. The changes in adiponectin and acylated ghrelin after 1 month suggest a shift towards increased glucose disposal and utilization, leading to fat store repletion after a period of tissue starvation. Later, chronic insulin treatment and metabolic equilibrium would normalize their levels.

Recently developed models have failed to find an association between resistin levels, glycemia or insulinemia (25), in agreement with our unchanging resistin levels. Moreover, even the association between resistin, obesity, and insulin resistance is controversial in humans $(26,27)$.

In conclusion, the relationship of BMI with acylated ghrelin and adiponectin levels in newly diagnosed T1DM patients seems to be influenced by their role in the metabolic adaptation to this disease. In addition, the lack of changes in resistin levels suggests that it is probably not involved in the adaptation to the metabolic changes in T1DM, whereas changes in acylated ghrelin might indicate its potential involvement in glucose homeostasis. Taken together, these results suggest that these peptides might afford additional metabolic information in children with T1DM.

\section{Acknowledgements}

The authors wish to thank Dr Julie A Chowen for the critical review of the manuscript. Gabriel Á MartosMoreno is supported by the Fondo de Investigación Sanitaria (FIS CM05/00 100). This work was supported by grants from Fondo de Investigación Sanitaria (FIS PI040817), Comunidad de Madrid (08.5/0002/2003) and the Fundación Endocrinología y Nutrición.

\section{References}

1 Sinha A, Formica C, Tsalamandris C, Panagiotopoulos S, Hendrich E, DeLuise M, Seeman E \& Jerums G. Effects of insulin on body composition in patients with insulin-dependent and noninsulin-dependent diabetes. Diabetic Medicine 199613 40-46. 
2 Kershaw EE \& Flier JS. Adipose tissue as an endocrine organ. Journal of Clinical Endocrinology and Metabolism $2004 \mathbf{8 9}$ 2548-2556.

3 Meier U \& Gressner AM. Endocrine regulation of energy metabolism: review of pathobiochemical and clinical chemical aspects of leptin, ghrelin, adiponectin, and resistin. Clinical Chemistry 200450 1511-1525.

4 Berg AH, Combs TP, Du X, Brownlee M \& Scherer PE. The adipocyte-secreted protein Acrp30 enhances hepatic insulin action. Nature Medicine 20017 947-953.

5 Lihn AS, Pedersen SB \& Richelsen B. Adiponectin: action, regulation and association to insulin sensitivity. Obesity Reviews 20056 13-21.

6 Reinehr T, Roth C, Menke T \& Andler W. Adiponectin before and after weight loss in obese children. Journal of Clinical Endocrinology and Metabolism 200489 3790-3794.

7 Jain SK, Kannan K, Lim G, Matthews-Greer J, McVie R \& Bocchini JA Jr. Elevated blood interleukin-6 levels in hyperketonemic type 1 diabetic patients and secretion by acetoacetatetreated cultured U937 monocytes. Diabetes Care 200326 2139-2143.

8 Hoffman WH, Burek CL, Waller JL, Fisher LE, Khichi M \& Mellick LB. Cytokine response to diabetic ketoacidosis and its treatment. Clinical Immunology 2003108 175-181.

9 Bruun JM, Lihn AS, Verdich C, Pedersen SB, Toubro S, Astrup A \& Richelsen B. Regulation of adiponectin by adipose tissue-derived cytokines: in vivo and in vitro investigations in humans. American Journal of Physiology. Endocrinology and Metabolism 2003285 E527-E533.

10 Argente J, Barrios V, Chowen JA, Sinha MK \& Considine RV. Leptin plasma levels in healthy Spanish children and adolescents, children with obesity, and adolescents with anorexia nervosa and bulimia nervosa. Journal of Pediatrics $1997131833-838$.

11 Soriano-Guillen L, Barrios V, Chowen JA, Sánchez I, Vila S, Quero J \& Argente J. Ghrelin levels from fetal life through early adulthood: relationship with endocrine and metabolic and anthropometric measures. Journal of Pediatrics 2004144 30-35.

12 Soriano-Guillen L, Barrios V, Lechuga-Sancho A, Chowen JA \& Argente J. Response of circulating ghrelin levels to insulin therapy in children with newly diagnosed type 1 diabetes mellitus. Pediatric Research 200455 830-835.

13 Soriano-Guillen L, Barrios V, Martos G, Chowen JA, CamposBarros A \& Argente J. Effect of oral glucose administration on ghrelin levels in obese children. European Journal of Endocrinology 2004151 119-121.

14 Celi F, Bini V, Papi F, Santilli E, Ferretti A, Mencacci M, Berioli MG, De Giorgi G \& Falorni A. Circulating acylated and total ghrelin and galanin in children with insulin-treated type 1 diabetes: relationship to insulin therapy, metabolic control and pubertal development. Clinical Endocrinology (Oxford) 200563 139-145.

15 Gauna C, Delhanty PJ, Hofland LJ, Janssen JA, Broglio F, Ross RJ, Ghigo E \& van der Lely AJ. Ghrelin stimulates, whereas desoctanoyl ghrelin inhibits, glucose output by primary hepatocytes. Journal of Clinical Endocrinology and Metabolism 200590 1055-1060.

16 Hernández M, Castellet J, Narvaiza JL, Rincón JM, Ruiz I \& Sánchez E. In Curvas y tablas de crecimiento. Instituto de Investigación sobre Crecimiento y Desarrollo. Fundación Faustino Orbegozo. Madrid: Editorial Garsi, 1988.
17 Perez-Bravo F, Santos JL, Carrasco E, Calvillan M, Albala C, Puig-Domingo M, Piquer S \& De Leiva A. Transmission of high-risk HLA-DQB1 alleles in Chilean type 1 diabetic patients and their parents: stratification by the presence of ICA or GAD65 autoantibodies. Autoimmunity 200133 285-291.

18 Broglio F, Gottero C, Prodam F, Gauna C, Muccioli G, Papotti M, Abribat T, Van Der Lely AJ \& Ghigo E. Non-acylated ghrelin counteracts the metabolic but not the neuroendocrine response to acylated ghrelin in humans. Journal of Clinical Endocrinology and Metabolism 200489 3062-3065.

19 Gauna C, Meyler FM, Janssen JA, Delhanty PJ, Abribat T, van Koetsveld P, Hofland LJ, Broglio F, Ghigo E \& van der Lely AJ. Administration of acylated ghrelin reduces insulin sensitivity, whereas the combination of acylated plus unacylated ghrelin strongly improves insulin sensitivity. Journal of Clinical Endocrinology and Metabolism 200489 5035-5042.

20 Carlson MG \& Campbell PJ. Intensive insulin therapy and weight gain in IDDM. Diabetes 199342 1700-1707.

21 Schaffler A, Herfarth H, Paul G, Ehling A, Muller-Ladner U, Scholmerich J \& Zietz B. Identification of influencing variables on adiponectin serum levels in diabetes mellitus type 1 and type 2 . Experimental and Clinical Endocrinology and Diabetes 2004112 383-389.

22 Lihn AS, Richelsen B, Pedersen SB, Haugaard SB, Rathje GS, Madsbad S \& Andersen O. Increased expression of TNF-alpha, IL-6, and IL-8 in HALS: implications for reduced adiponectin expression and plasma levels. American Journal of Physiology. Endocrinology and Metabolism 2003285 E1072-E1080.

23 Wolfe BE, Jimerson DC, Orlova C \& Mantzoros CS. Effect of dieting on plasma leptin, soluble leptin receptor, adiponectin and resistin levels in healthy volunteers. Clinical Endocrinology 200461 332-338.

24 Tsuchida A, Yamauchi T \& Kadowaki T. Nuclear receptors as targets for drug development: molecular mechanisms for regulation of obesity and insulin resistance by peroxisome proliferator-activated receptor gamma, CREB-binding protein, and adiponectin. Journal of Pharmacological Sciences 200597 164-170.

25 Lee JH, Bullen JW Jr, Stoyneva VL \& Mantzoros CS. Circulating resistin in lean, obese, and insulin-resistant mouse models: lack of association with insulinemia and glycemia. American Journal of Physiology, Endocrinology and Metabolism 2005288 E625-E632.

26 Lee JH, Chan JL, Yiannakouris N, Kontogianni M, Estrada E, Seip R, Orlova C \& Mantzoros CS. Circulating resistin levels are not associated with obesity or insulin resistance in humans and are not regulated by fasting or leptin administration: cross-sectional and interventional studies in normal, insulin-resistant, and diabetic subjects. Journal of Clinical Endocrinology and Metabolism $2003 \mathbf{8 8} 4848-4856$.

27 Degawa-Yamauchi M, Bovenkerk JE, Juliar BE, Watson W, Kerr K, Jones R, Zhu Q \& Considine RV. Serum resistin (FIZZ3) protein is increased in obese humans. Journal of Clinical Endocrinology and Metabolism $2003 \mathbf{8 8} 5452-5455$.

Received 21 March 2006

Accepted 1 August 2006 